Article

\title{
The Efficiency of the Sustainable Development Policy for Energy Consumption under Environmental Law in Thailand: Adapting the SEM-VARIMAX Model
}

\author{
Pruethsan Sutthichaimethee *(i) and Sthianrapab Naluang \\ School of Law, Assumption University, 592/3 Ramkhamhaeng 24, Hua Mak, Bangkok 10240, Thailand \\ * Correspondence: pruethsan.s@chula.ac.th; Tel.: +66-639-645-195
}

Received: 25 June 2019; Accepted: 9 August 2019; Published: 12 August 2019

\begin{abstract}
This research aims to predict the efficiency of the Sustainable Development Policy for Energy Consumption under Environmental Law in Thailand for the next 17 years (2020-2036) and analyze the relationships among causal factors by applying a structural equation modeling/vector autoregressive model with exogenous variables (SEM-VARIMAX Model). This model is effective for analyzing relationships among causal factors and optimizing future forecasting. It can be applied to contexts in different sectors, which distinguishes it from other previous models. Furthermore, this model ensures the absence of heteroskedasticity, multicollinearity, and autocorrelation. In fact, it meets all the standards of goodness of fit. Therefore, it is suitable for use as a tool for decision-making and planning long-term national strategies. With the implementation of the Sustainable Development Policy for Energy Consumption under Environmental Law (S.D.EL), the forecast results derived from the SEM-VARIMAX Model indicate a continuously high change in energy consumption from 2020 to 2036the change exceeds the rate determined by the government. In addition, energy consumption is predicted to have an increased growth rate of up to $185.66 \%$ (2036/2020), which is about $397.08 \mathrm{ktoe}$ (2036). The change is primarily influenced by a causal relationship that contains latent variables, namely, the economic factor $(E C O N)$, social factor (SOCI), and environmental factor (ENVI). The performance of the SEM-VARIMAX Model was tested, and the model produced a mean absolute percentage error (MAPE) of $1.06 \%$ and a root-mean-square error (RMSE) of $1.19 \%$. A comparison of these results with those of other models, including the multiple linear regression model (MLR), back-propagation neural network (BP model), grey model, artificial neural natural model (ANN model), and the autoregressive integrated moving average model (ARIMA model), indicates that the SEM-VARIMAX model fits and is appropriate for long-term national policy formulation in various contexts in Thailand. This study's results further indicate the low efficiency of Sustainable Development Policy for Energy Consumption under Environmental Law in Thailand. The predicted result for energy consumption in 2036 is greater than the government-established goal for consumption of no greater than $251.05 \mathrm{ktoe}$.
\end{abstract}

Keywords: environmental law; latent variables; structural equation modelling; sustainable development policy; energy consumption; vector autoregressive model

\section{Introduction}

Sustainable development policy has been given increasingly serious attention around the world. It is used side by side to define national strategies of various countries for different time scales; short-term, medium-term and long-term [1-3]. In the area of Environmental Law specifically, it is part of the driving mechanisms to run such a policy for economic, social and environmental sustainability [4-6]. In order to make national development more sustainable, mutual coordination between the national 
management policy and legislation is required, especially integrating and incorporating environmental law in order to achieve long-run sustainability [6-8].

For Thailand, the main goal of sustainable development policy is to play a core role in creating sustainability, as stated in the constitution of the Kingdom of Thailand B.E. 2560, with the say of government policy under Article 72. In addition, the government is given the role of managing the environment under Article 57, and protecting it under Article 58. Furthermore, this version of the constitution provides a new provision to guarantee the rights of the people and community toward the environment under Article 43, as well as grant the right to charge the government or government agencies with the responsibility for protecting the environment under Article 41 . While the National Environmental Quality Promotion and Preservation Act (Version 2) B.E. 2561 [9] comes with a significant focus on the formulation of environmental protection policies, as follows: (1) promoting the participation of people and NGOs in protecting the environment, particularly Articles 6 to 8; (2) establishing an Environmental Committee under Articles 12 to 21; (3) establishing a Pollution Control Committee under Articles 52 to 54 as the main organization to determine pollution control policy; (4) establishing the Environment Fund under Articles 22 to 31; (5) overseeing the environmental quality management short-term plans of 5 and 20 years under Articles 35 to 41, which is deemed significant, especially the Sustainable Development Policy for Energy Consumption under Environmental Law; (6) establishing environmental standards under Articles 32 to 34; (7) establishing environmental protection zones under Articles 42 to 45; (8) establishing pollution control zones under Articles 59 to 63; (9) assessing environmental impact under Articles 46 to 51/7 and 101/1 to 101/2; and (10) determining the civil responsibility of polluters under Articles 96 to 111.

In fact, from 1995 to 2018, Thailand has tremendously improved its economic development, when Gross Domestic Product (GDP) of Thailand improves with an increasing growth rate [10]. The Thai government has continuously established policies to increase in national revenues. The main revenue-generated bases the government has attended to are the continuation of export activities to major trading partners, while increasing the diversification of exported goods with good quality and strong marketability. This is done together with establishing various measures to broadening market shares $[9,10]$. In addition, it can be observed that the government has adopted certain strategies by allowing others countries engaging in local investments in various industrial projects. Besides, the government allows joint investments together with other foreign countries within the main industries of Thailand, as well as promotes Thailand as a strategically important production base. These strategies are from both proactive and receptive approaches, including tax exemption for foreigners to land production bases in Thailand, and the promotion of international tourism, for instance [11]. Besides, the government seeks to promote and implement social policies at the same time. This has resulted in development and an increased growth rate. In general, the government has played a significant role in formulating different policies, such as the promotion in Employment Opportunities, Health and Illness, Social Security, Consumer Protection, as well as monitoring and follow-up programs $[12,13]$. However, with robust development in economic and social development, it has simultaneously led to the environmental change as well. By noting from the past (1995) until today (2018), the greenhouse gas rate has increased continuously, especially the increment of $\mathrm{CO}_{2}$ emission from the energy-based sector. This cause of energy consumption tends to rise continuously in all sectors. The most sectors are the electronic sector, transportation sector and industrial sector, generating greenhouse gas up to 90.05 percent $(2018)[13,14]$. From the above discussion, it can be noticed that Thailand has succeeded with economic and social policy, yet environmental policy is not much given serious attention in development; resulting in the reduction of carrying capacity in the ecosystem. One of major reasons is that the inefficiency and weak enforcement of Environmental Law [9]. Moreover, there is still a lack of tools in the implementation of the Sustainable Development Policy in Energy Consumption under Environmental Law in Thailand to drive the nation towards the sustainability. 
Establishing a sustainable development policy for Thailand is considered to be an important strategy for driving the country toward sustainability. This requires a powerful tool for ensuring that the outcomes of national policies and plans have the highest possible efficiency and effectiveness over shortand long-term periods. Meanwhile, the government can aim to mitigate or solve problems, particularly during the formulation process of the Sustainable Development Policy in Energy Consumption under Environmental Law. This is also seen as a necessity for national development under the national strategic plan because of its effects on economic, social, and environmental dimensions, which constitute part of a holistic approach to developing the nation. Any country that is able to strategize such an approach and turn it into reality will benefit by attaining sustainability in both the short term and long term. In the long run, there is a high possibility that problems and hurdles will occur within and outside the nation, and these challenges are usually difficult to control or even monitor. Thus, strategic planning must evolve from strong knowledge, capacities, and resources, since the output of this action will determine the future of the nation. To date, the implementation of Thailand's Sustainable Development Policy in Energy Consumption under Environmental Law is still weak and poorly planned. Moreover, there is still no single tool to facilitate a solution to this matter, which affects economic, social, and environmental systems. Therefore, determining the relationship among factors by developing a causal model that integrates economic, social, and environmental aspects, as well as enforcing the environmental law, has become crucial. In addition, studying the relevant research (discussed in the literature reviews section) reveals a gap that no other studies have focused on when proposing models for different contexts in various sectors. In fact, the previous studies have applied the same research methodologies, leading to insufficient analysis in different contexts and sectors. Therefore, the paper has understood the gap and problem, and starts introducing the SEM-VARIMAX model as a tool for national policy formulation and in all short-term, medium and long-term future planning.

\section{Literature Review}

Upon reviewing the relevant literature from available resources, many streamlined studies have highlighted the evolving concept of sustainable development, which has made significant progress in different areas worldwide. Zhou et al. [15] investigated the evolution of sustainable development-related politics and laws in China, and they found that ecological civilization tends to broadly tackle problems, focus on public participation, as well as fill the gap in environmental legislation. In their review of the historical experience of successful development in the Su-style furniture industry in the Ming Dynasty using a diamond model, Fan and Feng [16] found that style, material, skill, and government contributions, as well as consumer demand, had significant roles in gaining competitive advantages during that period. In fact, Boyd et al. [17] reviewed 10 Clean Development Mechanism (CDM) projects according to their sustainability privileges. The study later illustrated that sustainable development concerns have been marginalized in some countries. Joseph [18] has observed that, most Malaysian local authorities' personnel do not understand the concept of sustainable development and sustainability reporting. In Bangladesh, Bahauddin [19] revisited the environmental protection history and other relevant interests. This visit has made a new initiative possible by paving core best practices. Strengthening and restructuring key environmental organizations are of few guidelines that must be done. As of understanding the concept of sustainable development, Rivera [20] studied Sustainable Development Goals (SDGs), and investigated whether any work has been done between science and policy. The study pointed out the failure to fulfill some set criterion. Ali et al. [21] have investigated the connection between environmental degradation and economic growth in Pakistan through a test of Environmental Kuznets Curve along with Autoregressive Distributed Lag (ARDL) model. There comes the result of which inverted U-shaped relationship exists between those two spaces, implying the positive impact of population density on per capita carbon emission. In addition, the rise of energy consumption tends to degrade the environmental aspect. However, the role of multi-stakeholder partnerships dealing with climate change and sustainable 
development for developing countries was examined by Pinkse and Kolk [22]. Upon analysis, it revealed the participation of all parties in the creation of linkage between issues. To Choi and $\mathrm{Ng}$ [23], they attempted to understand consumers' responses on two sustainability concepts in terms of environmental and economic aspects, along with price. The study explained a positive consumer behavior on two-sustainability-focused companies, while there was no in favor of low price reaction when the consumers are aware of the firm with poor environmental sustainability. Amesheva [24] touched upon the environmental impact on development and social inequality along with recent legislative measures. As of a result, it revealed the need of reformation due to governance challenge. In the meanwhile, Bakari [25] shad some highlights on the challenges of sustainable development implementation in term of global governance, confirming less impact on the whole global governance system. While the need of economy and environment was found by Martin [26] with the affirmation of the assessment of environmental and welfare policies. The main aim of all the relevant studies in the review was to address the concept of sustainability in economic, social, and environmental aspects.

However, the UN Secretariat [27] reported the possible continuation of Urban development, and this aspect can be further improved by adopting the New Urban Agenda at the United Nations Conference on Housing and Sustainable Urban Development (Habitat III). Khalifa and Connelly [28] has found advantages to decision makers after the introduction of sustainable development indicators along with an index appropriate as compared to the current method of locally calculated Human Development Indices (HDI). In addition, Wuelser et al. [29] proposed an analytical framework assisting research on sustainable development by using theoretical conceptions and in-depth analysis by paving the setting of joint learning in policy making, shared visions and knowledge creation which in line with sustainable development's objectives. While Mueller et al. [30] discussed four different standards (ISO 14001, SA 8000, FSC and FLA), and revealed basic conditions for stakeholders to uphold, like CSR in supply chains, for instance. Based on other existing studies, Zhang et al. [31] evaluated the overall robustness of Ecological Footprint (EF) for decision-making on sustainability, while seeking ways to improve the EF. The new three methods were proposed, a correction factor for bio-capacity measurement, three-dimensional ecological footprint model and modified carbon footprint measurement. To add on, Wang et al. [32] introduced the ecological carrying capacity intensity (EC Intensity) according to the revised version of three-dimensional ecological footprint (3DEF) model. The findings of the study disclosed that EC Intensity has raised slowly with stronger capacity for regional development. Singh and Debnath [33] did a study to comprehend the Clean Development Mechanism (CDM). The finding gave them the fact that sustainable development is reachable if there is an emphasis on strategic goals and mission.

On the other hand, Giddings et al. [34] integrated environment, economy, and society to sustainable development and this required more than technical changes and a shift in human worldview. With the investigation of Sapukotanage et al. [35] on the sustainable practices of the manufacturing firms in a developing nation in South Asia, there was evidence of such sustainable practices leading towards sustainable performance. Sutthichaimethee [36] predicted the sustainable development policy implementation in the sanitary and service sectors of Thailand by 2045 with the result of potential growth of Thai economy system by $25.76 \%$ along with changes. Gradually, the Greenhouse gas emissions are found to increase by $49.65 \%$. To Greaker et al. [37], they established a benchmark for climate policy at a national level. The greenhouse gas mitigation projects at certain cost and acquisitions of emission permits were part of the benchmark, as discussed in the study. It is also worth noting that many studies have shown the significance of why the concept comes into existence. Cetindamar and Husoy [38] understood why companies act environmentally responsible and that came with more than one reason, while ethical and economic reasons are found to be among the reasons. Bedore [39] further investigated the impact of new Canadian legislation, Federal Sustainable Development Act in 2008 on sustainable development. The result of this investigation pointed out the improvement of Canadian sustainable development planning systems due to this Act. Lee et al. [40] looked at Korea's official development assistance (ODA) projects in Sri Lanka as the basis of identifying policy issues on the 
sustainable development of developing countries, and the observation has shown the improvement made by the projects in term of environmental policy enhancement, public awareness, increased communication and cooperation between participating countries and follow-up management. While Aguilera-Caracuel et al. [41] sought to see the impact of institutional distance between the home and the host country, and the headquarters' financial performance on the environmental standardization decision among multinational companies. The finding showed that when an environmental institutional distance is high, it would slow down the standardization of environmental practices, while high-profit headquarters are ready to take part. Pires, Fidelis and Ramos [42] measured and compared local sustainable development based on common indicators by seeing through some constraints and achievements. As of their finding, it revealed that the communication, limited political support, and application of such indicators are the main issues, and these limit indicators' capacity towards sustainable development.

Giannetti, Demetrio, Bonilla, Agostinho and Almeida [43] later diagnosed an environmental energy of Brazil compared to Russia, India, China, South Africa and United States. The study concluded what actions may be put in place; reducing total energy use in developed economies and decreasing exportation of indigenous resources in developing economies. Wysokinska [44] analyzed the impact of eight UN Millennium Development Goals implementation, drawing a further implication that triggers the fight against poverty, hunger, disease, and environmental destruction, rather than mitigate the risk of climate change, global hunger, and the economic fallout. Panzaru and Dragomir [45] firmly stood with high importance of managers' involvement in predicting economic growth for sustainable and economic development. Byrch et al. [46] have found the participant maps in promoting business, and accommodating economic growth and development, as the key player in the sustainable development after they revisited the meaning of sustainable development held by New Zealand. In addition, Casey and Galor [47] examined the carbon emissions in terms of their effect of lower fertility. Regardless of its complexity, population policies were found to be part of the approach to tackling global climate change. Also, Ramakrishnan et al. [48] have established an environmental model for economic growth by integrating sustainability principles. The model produced a number of outcomes, showing the energy demand would decrease when the regional agricultural share rises.

However, another exploration on the engagement of sustainable development with legislation gives a better understanding of how such development can be enforced. Ladan [49] tried to establish a significant nexus between the SDGs, human rights and climate change. This study has concluded that national law must come into play in order to archive the above objective. Craig et al. [50] sought to study the flexibility and stability in governance. They came into a conclusion of which an attention to process and procedure along with increased use of substantive standards would improve and better the substantive flexibility level to operate with legitimacy and fairness. Whereas, Wang [51] reviewed ongoing debates pertaining to environmental regulation in developing countries and other aspects. During this exploration, China has been found to face environmental problems, yet China has made a serious long-term campaign to confront these issues. Furthermore, Bartel and Barclay [52] have applied Motivational Posture Theory to examine motivational attitudes on relevant areas, including government, environmental problems, environmental laws and regulations and farm management behaviors in the context of Australian agriculture and environmental regulation. Here, the compliance was found and supported both government and regulations. At the same arena, Kim and Mackey [53] exhibited the international environmental law and found it to be a complex network of treaties and institutions. Huber [54] visited the recurrent political challenge for environmental policymakers, and has found the matter of regulatory cost and change-resistant legal and institutional policy arrangements becomes the main challenge. Alongside, Tecklin et al. [55] explored the environmental policymaking process while examining the character and impact of the environmental governance. Here, the study was evident of the strongly market-enabling quality for the governance instead of the market-regulating one. In addition, Zeben [56] managed to introduce additional criteria for competence allocation, 
and this further expanded its application in the regulatory process, be it norm setting, implementation or enforcement.

If other studies are put further into the discussion, Bodansky [57] clarified the nature of the legitimacy challenge on environmental problem with the claim of decision-making deficit for both individual states and international institutions. With his study of the European Union, it demonstrated that the magnitude of legitimacy positively depends on the strength of the institution. Heinzerling [58] encouraged the lawyers furthering their efforts to attain proper laws and institutions that can reduce the effect of the polluting state. In China, Chang and Wang [59] began to tap on climate change, including most environmental governance system. However, the results showed that pollution discharge permit system is built upon insufficient resources, leading to differing standards for different places in China. Nonetheless, Periconi and Jokajtys [60] pointed out the importance of modern environmental laws in New York restricting on certain harmful practices for the environment, and those laws shall be continued for the current applications. Latham, Schwartz and Appel [61] investigated the intersection of tort and environmental law, and later found that such intersection should be narrowed in order to harmonize both statutory and common law. To this extent, Wood [62] addressed the failure of environmental law in the United States as all juristic agencies allowed so. In order to reduce such failure, the study suggested that all government institutions shall be held accountable for their discretions. While Gibson [63] put 10 basic design principles as part of environmental assessment consideration in Canada, triggering a new trend of global attention for the future version of environmental assessment. In particular, Fast and Fitzpatrick [64] explored the Environmental Rights Act of the Government of Manitoba in Bill 20, indicating the importance of the Environmental Bill of Rights in the legislation, and it must be placed in the on-going efforts to restructure the provincial environmental protection system. De Moerloose [65] has further compiled papers for the "2016 Law and Development Conference: From the Global South Perspectives." This compilation exhibited the disconnection between law and development, and that leads to further action on reconnecting law with development.

Nevertheless, Tania [66] has reviewed the trade-sustainable development debate in the view of Rio+20 and its relevant green economic policy. Here, the market access barriers for least developed country (LDC) is turned out to be the main concern for developed countries towards the sustainable development. Whereas Chepaitis and Panagakis [67] engaged legal philosophy in bridging individual capacity and environmental degradation, and this justified the return of greenhouse gases in the atmosphere with the absence of individual responsibility. Miao [68] analyzed the situations of the right to justice in environmental matters in China from a legal perspective. The study's findings have shown three main focuses in order to protect such right; engaging, effectiveness, and efficiency. To a broader aspect, Pourhashemi et al. [69] examined the international treaties and the United Nations Framework on Climate Change Convention in particular, as well as to evaluate the existing forms of legal and operational protection in relation with climate change. From this study, they have found many issues, and a failure to protect the rights of refugees and immigrants comes before hand. By tackling the above issues, it could actually result in efficient management of this crisis and stop the possible chaos across the globe. While Ruhl [70] investigated the context and policy dynamics of climate change and its trends while exploring normative and structural impacts on how environmental law fits in. The study has illustrated three main areas that environmental law plays: pollution control and ecological conservation, climate change mitigation, and its adaptation.

The structural equation model is a forecasting method commonly used in studies in a variety of contexts and for various objectives. Moreno et al. [71] applied a Structural Equation Model (SEM) and Confirmatory Factor Analysis (CFA) to understand the nature of classroom conflict in schools in Spain. Boccia and Sarnacchiaro [72] examined consumer attitudes pertaining to companies' corporate social responsibility initiatives by applying a structural equation model. Baumgartner and Homburg [73] assessed the applications of structural equation modeling in marketing and consumer research in three aspects, examining problematic issues and suggesting ways to improve them. Furthermore, Mai et al. [74] analyzed latent variables by comparing exploratory structural equation modeling 
(ESEM) with structural equation modeling (SEM) and manifest regression analysis (MRA). In their study, ESEM was determined to provide the least biased estimation of regression coefficient. Ryu and Mehta [75] examined multilevel factorial invariance in n-level structural equation modeling (nSEM) by optimizing a multigroup multilevel confirmatory factor analysis. Lei and Lomax [76] examined structural equation modeling under nonnormality conditions using two different estimation methods. Significantly, the study showed no effect of estimation methods and nonnormality conditions on the standards errors of parameter estimates. Cugnata et al. [77] used Bayesian Networks (BN) to investigate factors regarding overall customer satisfaction to determine appropriate actions to improve customer satisfaction. Nylund et al. [78] simulated a study on the performance of latent class analysis (LCA), factor mixture model (FMA) and growth mixture model (GMM) to identify the number of classes in different sample sizes. In Japan, Saito et al. [79] estimated the effects of daily $\mathrm{CO}_{2}$ exchange on environmental variables by using a path analysis, which showed soil temperature having a significant impact on ecosystem $\mathrm{CO}_{2}$ exchange throughout the year. Yang and Yuan [80] proposed ridge generalized least squares (RGLS) as part of a structural equation modeling procedure for the development of formulas. Here, RGLS were found beneficial for enhancing parameter estimate efficiency.

A number of studies in various countries have attempted to optimize different forecasting models. In China, Chang et al. [81] deployed a fuzzy-based grey modeling (GM) procedure in the estimation of sulfur dioxide emissions. The study showed the effectiveness of the model and the forecasting indicated a decline in such emissions. Wang et al. [82] predicted air temperature by introducing a new integrated model, the Variational Mode Decomposition-Autoregressive Integrated Moving Average (VMD-ARIMA), which was found to be effective in providing accurate temperature forecasting. Ma et al. [83] predicted provincial vehicle ownership utilizing the Gompertz model, estimating a rapid growth in vehicle ownership in each province by 2050. Zhao et al. [84] used a giant information history simulation to estimate the value-at-risk (VaR) of oil prices, analyzing how various VaR factors from online news sources can most accurately measure crude oil VaR. Xiong et al. [85] incorporated a novel linear time-varying grey model $(1, \mathrm{~N})$ to predict haze while comparing it with the original GM model, finding that the novellinear time-varying GM model outperformed the original model. In New Zealand, Zhao et al. [86] explored the connection between household energy use and residential building costs by using time series methods, the exponential smoothing method, the autoregressive integrated moving average (ARIMA) model and the artificial neutral networks (ANNs) model. In the study, the ANNs model was proven to be the most accurate for cost forecasting. In the U.S., Barari and Kundu [87] revisited the role of the U.S. Federal Reserve in triggering the recent housing crisis by using a VAR model and found that federal funds rate did not lead to house price increases. Looking at the European Union, Tucki et al. [88] proposed a new method to investigate the development of the electromobility sector in Poland and the EU states. Their study concluded that Poland and the EU states require new approaches in terms of energy management and vehicle operation management. In Africa, Ahmed et al. [89] applied the ANNs model to forecast GRACE data of African watersheds and found that the model provided the most accurate forecast. Ramsauer et al. [90] adapted a Factor-Augmented Vector Autoregression Model (FAVAR) with an extension of a Kalman Filter for Factors to measure the impact of monetary policy in a case study.

From the review of the relevant literature, it was found that the research patterns and methodologies varied in terms of the research process and the statistics used to create forecasting models. This study is distinct from others; it addresses a gap in the research while also developing the research process and pattern and applying advanced statistics. In addition to this, the authors conducted other studies to support the forecasting models with different indicators. Those studies are titled "The efficiency of long-term forecasting model on final energy consumption in Thailand's petroleum industries sector: enriching the LT-ARIMAXS Model under a sustainability policy" [91] and "A relational analysis model of the causal factors influencing $\mathrm{CO}_{2}$ in Thailand's industrial sector under a sustainability policy adapting the VARIMAX-ECM Model" [92]. The mentioned studies used a stationary process, while adapting the concept of a co-integration and error correction mechanism in order to analyze 
the real impact of the indicators on the dependent variable. This research extends and develops the above studies in depth using a model with improved accuracy by optimizing the advantages of those studies. From those advantages, this study analyzes direct and indirect effects, and it adjusts each latent variable toward equilibrium. The output can be used as a tool to formulate future national policies and plans. Furthermore, this study aims to create new knowledge and act as a guide for research and education. Importantly, this study features a model that is applicable to various sectors and contexts, and it was developed with the aim of producing efficient and effective study outcomes. As mentioned earlier, this study applied advanced statistics in a proper context to make the model applicable to different sectors. As a whole, this construct is called "Structural Equation Modeling-Vector Autoregressive with Exogeneous Variables Model" (SEM-VARIMAX Model). The research also utilizes Linear Structural Relations (LISREL) [93] software along with Econometric Views (EVIEWS) [94,95]. The above-mentioned model is assessed in term of its Model Validity and Best Modelling, as well as "Best Linear Unbiased Estimated (BLUE) assessment. This is to ensure that there will be no issues of Heteroskedasticity, Multicollinearity, and Autocorrelation. Once the complete model is obtained, it is then deployed to analyze the future trend together with qualitative analysis. The Model Validity Test is done through Triangulation. The research flow is explained below, as shown in Figure 1.

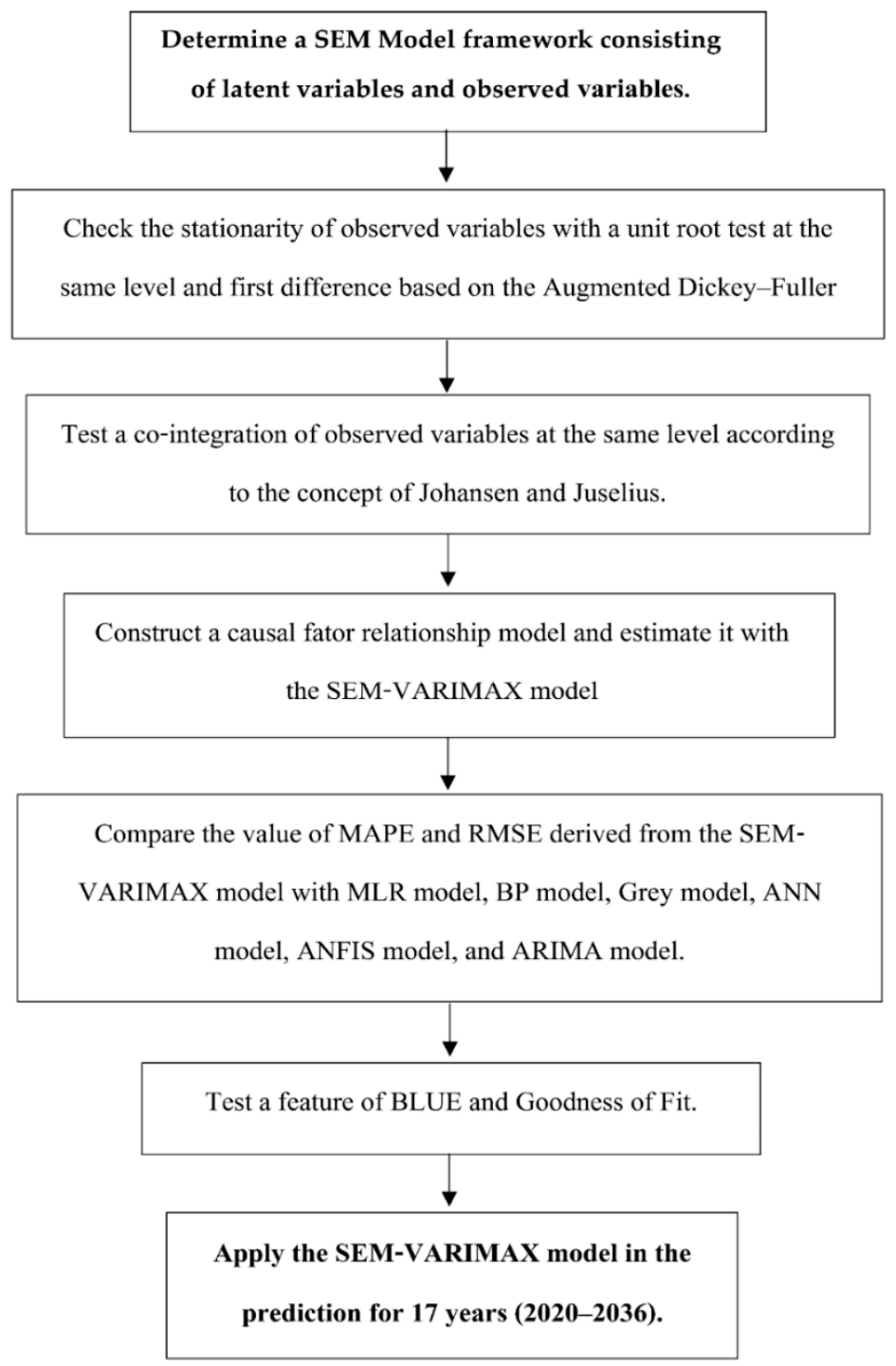

Figure 1. The flowchart of the structural equation modeling/vector autoregressive model with exogenous variables (SEM-VARIMAX) model. 
1. Determine a variable framework based on the SEM-VARIMAX model, which contains both latent variables of Sustainable development policy under environmental law (S.D.EL), economic $(E C O N)$, social $(S O C I)$, and environmental $(E N V I)$, and observed variables of Sustainable development policy under environmental law indicators, Error Correction Mechanism $\left(E C M_{t-1}\right)$ and energy consumption $(E C)$. As of the economic indicators, there are per capita GDP (GDP), urbanization rate $(U R)$, industrial structure $(I S)$, net exports $(E-M)$, indirect foreign investment $(I F)$, foreign tourists $(F T)$. The social indicators are employment $(E M)$, health and illness $(H I)$, social security $(S S)$, consumer protection $(C P)$. The environmental indicators include Carbon Dioxide Emissions $\left(\mathrm{CO}_{2}\right)$ and energy intensity $(E I)$.

2. Examine and check the stationarity of observed variables with a unit root test based on the concept of the Augmented Dickey-Fuller [96].

3. Test the co-integration of observed variables at the same level [97-99].

4. Construct a causal factor relationship model and estimate its relationship with the SEM-VARIMAX model along with other test of BLUE characteristic and its Goodness of Fit $[36,100]$.

5. Compare the effectiveness of the SEM-VARIMAX model with other models, including with MLR model, BP model, Grey model, ANN model, ANFIS model, and ARIMA model. through a performance measure of MAPE and RMSE [101,102].

6. Forecast the future Sustainable Development policy for energy consumption under Environmental Law with the use of a sample indicator, which is energy consumption $(E C)$, by deploying the SEM-VARIMAX model for the year of 2020 to 2036, totaling 17 years. The flowchart of the SEM-VARIMAX model is shown below.

\section{Materials and Methods}

The SEM-VARIMAX was developed through the application of advanced statistics, consisting of the causal factor relationship called structural equation modeling (SEM), and the estimation of such a relationship with the vector autoregressive model. The model was structured to be the best model, hereafter referred to as the SEM-VARIMAX model. Furthermore, the model is characterized with the best linear unbiased estimate, and is not spurious. The details are provided below.

\subsection{SEM-VARIMAX Model}

Structural equation modeling (SEM) is a second-generation model, which can analyze the relationships between multiple levels of SEM. This is inclusive of completely analyzing relationships in the inner model (structure model) and outer model (measurement model). This feature differs from first generation modeling, such as regression analysis, ANOVA, and MANOVA, which are used to analyze a single subject at a time and so may take longer for the path model. Even though the outcome is no different, of which the study findings is parallel with this result, it is not a numerical value of regression coefficients, statistical values $t$ (t-test) and other indicators. This is because these values are commonly different as their method is different; however, they still have similar values $[72,73,103]$.

SEM produces models that indicate the relationships between variables, and it is explained below [104].

Given that $X=\left\{X_{1}, X_{2}, \ldots, X_{H}\right\}$ represent the observed value of the exogenous latent variable.

Given $\xi=\left\{\xi_{1}, \xi_{2}, \ldots, \xi_{H}\right\}$ is the exogenous latent variable (we may call the latent variable the score or component).

Given that $Y=\left\{Y_{1}, Y_{2}, \ldots, y_{K}\right\}$ represent the observed value of the endogenous latent variable.

Given $\eta=\left\{\eta_{1}, \eta_{2}, \ldots, \quad \eta_{K}\right\}$ is the endogenous latent variable.

The coefficient $\pi_{j}$ is the multiple regression coefficient.

The reflective relationship has been developed to positively connect observer variables (MV) and latent variables (LV), and it is a loading, and/or the regression coefficient must be a positive value. Yet, 
it is allowable to have a negative value, but such value tells us some issues with data. For instance, it indicates an incompatibility in the scale of measurement, and that the mean or variance does not reflect the real meaning of the data.

Therefore, the solution is to change the estimation method by using the Vector Autoregressive model at $\mathrm{p}: \operatorname{VAR}(\mathrm{p})$ as follows.

There are 2 series of time series, which are $Y_{t}$ and $Z_{t}$. They can be written in the VAR(p) model as shown below $[105,106]$.

$$
\begin{aligned}
& Y_{t}=a_{10}+a_{11,1} Y_{t-1}+a_{12,1} Z_{t-1}+a_{11,2} Y_{t-2}+a_{12,2} Z_{t-2}+\ldots+a_{11, p} Y_{t-p}+a_{12, p} Z_{t-p}+u_{1 t} \\
& Z_{t}=a_{20}+a_{21,1} Y_{t-1}+a_{22,} Z_{t-2}+a_{21,2} Y_{t-2}+a_{22,2} Z_{t-2}+\ldots+a_{21, p} Y_{t-p}+a_{22, p} Z_{t-p}+u_{2 t}
\end{aligned}
$$

If we have $n$ series of time series, including $X_{1 t}, X_{2 t}, \ldots, X_{n t}$, we will write that time series in the $\operatorname{VAR}(\mathrm{p})$ model as illustrated below.

$$
\begin{gathered}
X_{t}=A_{0}+A_{1} X_{t-1}+A_{2} X_{t-2}+\ldots+A_{p} X_{t-p}+u_{t} \\
\text { where } X_{t}=\left[\begin{array}{c}
X_{1 t} \\
X_{2 t} \\
\vdots \\
X_{n t}
\end{array}\right]_{n \times 1}, A_{0}=\left[\begin{array}{c}
a_{01} \\
a_{02} \\
\vdots \\
a_{0 n}
\end{array}\right]_{n \times 1}, A_{i}=\left[\begin{array}{ccc}
a_{11, i} & \cdots & a_{1 n, i} \\
a_{21, i} & \cdots & a_{2 n, i} \\
\vdots & \vdots & \vdots \\
a_{n 1, i} & \cdots & a_{n n, i}
\end{array}\right]_{n \times n}, i=1, \ldots, P, \text { and } u_{t}=\left[\begin{array}{c}
u_{1 t} \\
\vdots \\
u_{n t}
\end{array}\right]_{n \times 1}
\end{gathered}
$$

As for measuring the mean and variance of the $\operatorname{VAR}(\mathrm{p})$ model, the same method can be used as that of the VAR(1) model. When observing the VAR(p) model, the value of the parameter is many, that is constant in the number of $\mathrm{n}$. In addition, the parameters as the coefficient value of $X_{t-1}, X_{t-2}$, $\ldots, X_{t-p}$ are $n^{2}+n^{2}+\ldots+n^{2}=p n^{2}$. Hence, all parameters of the VAR model are $n+p n^{2}$. Here, it indicates that the greater the number of time series is by 1 unit or sequence of VAR is bigger by 1 unit, the parameters will also be greater at the same time. Thus, any time series used in the VAR model should be an impactful time series, that can explain each other's effect.

However, constructing a model as the best model requires a BLUE feature. In the actual context, there should be exogenous variables in the modelling. This simplifies that the model should have white noise and be free from a spurious in which heteroskedasticity, multicollinearity and autocorrelation are eliminated. The authors, therefore, developed a new model called the SEM-VARIMAX model, which effectively incorporates various exogenous variables in different contexts or various sectors. The details of the SEM-VARIMAX model are explained as follows [107].

$$
\begin{gathered}
Y_{t}=\beta_{10}-\beta_{12} Z_{t}+\gamma_{11} Y_{t-1}+\gamma_{12} Z_{t-1}+\varepsilon_{y t} \\
Z_{t}=\beta_{20}-\beta_{21} Y_{t}+\gamma_{21} Y_{t-1}+\gamma_{22} Z_{t-1}+\varepsilon_{y t} \\
B X_{t}=\Gamma_{0}+\Gamma_{1} X_{t-1}+\varepsilon_{y t}
\end{gathered}
$$

where $B=\left[\begin{array}{cc}1 & \beta_{12} \\ \beta_{21} & 1\end{array}\right], X_{t}=\left[\begin{array}{l}Y_{t} \\ Z_{t}\end{array}\right], \Gamma_{0}=\left[\begin{array}{l}\beta_{10} \\ \beta_{20}\end{array}\right], \Gamma_{1}=\left[\begin{array}{ll}\gamma_{11} & \gamma_{12} \\ \gamma_{21} & \gamma_{22}\end{array}\right], \varepsilon_{t}=\left[\begin{array}{c}\varepsilon_{y t} \\ \varepsilon_{z t}\end{array}\right]$.

When considering Equation (4), it indicates that $\varepsilon_{y t}$ will affect $Y_{t}$, while $Y_{t}$ will affect $Z_{t}$ when considering Equation (5) (or briefly written as $\varepsilon_{y t} \rightarrow Y_{t} \rightarrow Z_{t}$ ). Hence, we can say that $\operatorname{Cov}\left(Z_{t}, \varepsilon_{y t}\right) \neq 0$ or time series of $Z_{t}$ and $\varepsilon_{y t}$ are related, indicating the assumption of CLRM is incorrect. Therefore, the parameter estimation in Equation (4) will be a biased estimator. Even if the sample is large, it still finds that the probability of the estimator with the least squares method with not be as the actual value (inconsistent estimator). Equation (5) will also give the same result as above. 
However, when the SEM-VARIMAX model is transformed into a deformed model, or VAR(1) model by multiplying $B^{-1}$ throughout Equation (6), Equation (7) will be as follows $[94,108,109]$.

$$
X_{t}=A_{0}+A_{1} X_{t-1}+u_{t}
$$

where $A_{0}=B^{-1} \Gamma_{0}=\left[\begin{array}{l}a_{01} \\ a_{02}\end{array}\right], A_{1}=B^{-1} \Gamma_{1}=\left[\begin{array}{ll}a_{11} & a_{12} \\ a_{21} & a_{22}\end{array}\right]$ and $u_{t}=B^{-1} \varepsilon_{t}=\left[\begin{array}{l}u_{1 t} \\ u_{2 t}\end{array}\right]$, or rewritten as Equations (8) and (9) like below.

$$
\begin{aligned}
& Y_{t}=a_{10}+a_{11} y_{t-1}+a_{12} Z_{t-1}+u_{1 t} \\
& Z_{t}=a_{20}+a_{21} y_{t-1}+a_{22} Z_{t-1}+u_{2 t}
\end{aligned}
$$

We can see that the VAR(1) model will not cause any problems like what occurred in the SEM-VARIMAX(1) model. Besides, we can estimate the parameters in the VAR(1) model with the least squares method. By observing the SEM-VARIMAX(1) model and the VAR(1) model, it was found that

- The parameters in the VAR(1) model are actually caused by the parameters in the SEM-VARIMAX(1) model, or the parameters of both models are related.

- The number of parameters in the VAR(1) model was 9, namely the $a_{10}, a_{11}, a_{12}, a_{20}, a_{21}, a_{22}$, parameters of $\operatorname{Var}\left(u_{1 t}\right)$, the parameters of $\operatorname{Var}\left(u_{2 t}\right)$ and the parameter of $\operatorname{Cov}\left(u_{1 t}, u_{2 t}\right)$.

- The number of parameters in the SEM-VARIMAX(1) model was 10, namely the $\beta_{10}, \beta_{11}, \beta_{20}$, $\beta_{21}, \gamma_{11}, \gamma_{12}, \gamma_{21}, \gamma_{22}$, parameters of $\operatorname{Var}\left(\varepsilon_{1 t}\right)$ and the parameters of $\operatorname{Var}\left(\varepsilon_{2 t}\right)$.

It can be observed that the number of parameters in the VAR(1) model is less than the SEM-VARIMAX(1) model's. Even though all the parameters can be estimated in the VAR(1) model, we still cannot use the relationship between the parameters of both models to find the parameter estimator in the SEM-VARIMAX(1) model [91,92].

However, if we can place some limitations in the SEM-VARIMAX(1) model, then it would cause a reduction in the number of parameters to 9 , allowing us to use the parameter estimator in the VAR model(1) in discovering the parameter estimator of the SEM-VARIMAX(1).

As for the SEM-VARIMAX (p) model, it can run up to sequence (p) as determined in the study, aiming at benefiting future applications.

\subsection{Measurement of the Forecasting Performance}

In this research, tested the performance of the SEM-VARIMAX model by comparing it with other exiting models, like the MLR, BP, Grey, ANN, ANFIS, and ARIMA models. In this comparison, we use the MAPE and RMSE values to examine the forecasting accuracy in each model. The calculation equations are shown as follows [101-103]:

$$
\begin{gathered}
\text { MAPE }=\frac{1}{n} \sum_{i=1}^{n}\left|\frac{\hat{y}_{i}-y_{i}}{y_{i}}\right| \\
R M S E=\sqrt{\frac{1}{n} \sum_{i=1}^{n}\left(\hat{y}_{i}-y_{i}\right)^{2}}
\end{gathered}
$$

\section{Empirical Analysis}

\subsection{Screening of Influencing Factors for Model Input}

In this paper, the structure equation modeling framework was determined. Four factors were modelled as latent variables as follows: Sustainable development policy under environmental law (S.D.EL), economic (ECON), social (SOCI), and environmental (ENVI), while the observed variables 
comprised of 13 indicators inclusive of energy consumption $(E C)$. The economic indicators were per capita GDP $(G D P)$, urbanization rate $(U R)$, industrial structure $(I S)$, net exports $(E-M)$, indirect foreign investment $(I F)$, and foreign tourists $(F T)$. The social indicators are employment $(E M)$, health and illness $(H I)$, social security $(S S)$, consumer protection $(C P)$. The environmental indicators comprised Carbon dioxide emissions $\left(\mathrm{CO}_{2}\right)$ and energy intensity $(E I)$. This research analyzed the influence of the relationship of the causal factors with the SEM-VARIMAX model. All the causal factors used in the model must be stationary at the same level only. Here, the natural logarithm of every variable is taken, so that linear data can be obtained and tested for stationary. The value obtained from this process is then compared to MacKinnon critical value at level I (0) based on the Dickey-Fuller theory. In this paper, all variables were found to be non-stationary at level I (0). Therefore, those variables were carried forward to perform stationary tests at the first difference I (1), as illustrated in Table 1.

Table 1. Stationary at first difference I (1).

\begin{tabular}{ccccc}
\hline \multicolumn{2}{c}{ Stationary } & \multicolumn{3}{c}{ MacKinnon Critical Value } \\
\hline Variables & Tau Test & $\mathbf{1 \%}$ & $\mathbf{5 \%}$ & $\mathbf{1 0} \%$ \\
\hline$\Delta \ln (E C)$ & $-5.69^{* * *}$ & -4.15 & -3.20 & -2.50 \\
$\Delta \ln (G D P)$ & $-5.21^{* * *}$ & -4.15 & -3.20 & -2.50 \\
$\Delta \ln (U R)$ & $-5.16^{* * *}$ & -4.15 & -3.20 & -2.50 \\
$\Delta \ln (I S)$ & $-4.65^{* * *}$ & -4.15 & -3.20 & -2.50 \\
$\Delta \ln (E-M)$ & $-5.05^{* * *}$ & -4.15 & -3.20 & -2.50 \\
$\Delta \ln (I F)$ & $-4.50^{* * *}$ & -4.15 & -3.20 & -2.50 \\
$\Delta \ln (F T)$ & $-4.32^{* * *}$ & -4.15 & -3.20 & -2.50 \\
$\Delta \ln (E M)$ & $-4.29^{* * *}$ & -4.15 & -3.20 & -2.50 \\
$\Delta \ln (H I)$ & $-4.68^{* * *}$ & -4.15 & -3.20 & -2.50 \\
$\Delta \ln (S S)$ & $-4.91^{* * *}$ & -4.15 & -3.20 & -2.50 \\
$\Delta \ln (C P)$ & $-5.01^{* * *}$ & -4.15 & -3.20 & -2.50 \\
$\Delta \ln \left(C O_{2}\right)$ & $-5.85^{* * *}$ & -4.15 & -3.20 & -2.50 \\
$\Delta \ln (E I)$ & $-5.34^{* * *}$ & -4.15 & -3.20 & -2.50 \\
\hline
\end{tabular}

Notes: $E C$ is energy consumption, GDP is per capita GDP, UR is urbanization rate, IS is industrial structure, $E-M$ is the net exports, $I F$ is indirect foreign investment, $F T$ is foreign tourists, $E M$ is employment, $H I$ is health and illness, $S S$ is social security, $C P$ is consumer protection, $\mathrm{CO}_{2}$ is carbon dioxide emissions, $E I$ is energy intensity. *** denotes a significance, $\alpha=0.01$, compared to the Tau test with the MacKinnon critical value, $\Delta$ is the first difference, and $\ln$ is the natural logarithm.

Table 1 shows that all factors were stationary at the first difference or stationery at Level I (1). When calculating the Tau test of every causal factor, the values were found to be greater than the MacKinnon critical value, which indicates all causal variables were stationary at a significance level of $1 \%, 5 \%$, and $10 \%$. When all causal factors were stationary at the same level, we used them for the co-integration test proposed by Johansen and Juselius, as shown in Table 2.

Table 2. Co-integration test by Johansen and Juselius.

\begin{tabular}{|c|c|c|c|c|}
\hline \multirow{2}{*}{ 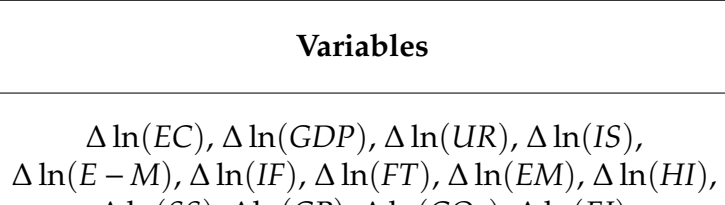 } & \multicolumn{2}{|c|}{ Co-Integration Test } & \multicolumn{2}{|c|}{$\begin{array}{c}\text { Mackinnon } \\
\text { Critical Value }\end{array}$} \\
\hline & $\begin{array}{c}\text { Trace statistic } \\
\text { test }\end{array}$ & $\begin{array}{l}\text { Max-Eigen } \\
\text { statistic test }\end{array}$ & $1 \%$ & $5 \%$ \\
\hline$\Delta \ln (S S), \Delta \ln (C P), \Delta \ln \left(C O_{2}\right), \Delta \ln (E I)$ & $215.75^{* * *}$ & $121.01^{* * *}$ & 15.25 & 11.75 \\
\hline
\end{tabular}




\subsection{Analysis of Co-Integration}

According to Table 2, the co-integration test result based on Johansen and Juselius shows that all causal factors, which were stationary at first difference in the SEM-VARIMAX model, were co-integrated at the significance level of $1 \%$ and $5 \%$ because the Trace statistic test value (215.75) and the Maximum Eigen statistic test value (121.01) were greater than the MacKinnon critical values at significance levels of $1 \%$ and $5 \%$, respectively. Therefore, all variables could be used in analyzing the impact of causal factors using the SEM-VARIMAX model, as shown in Figure 2 and Table 3.

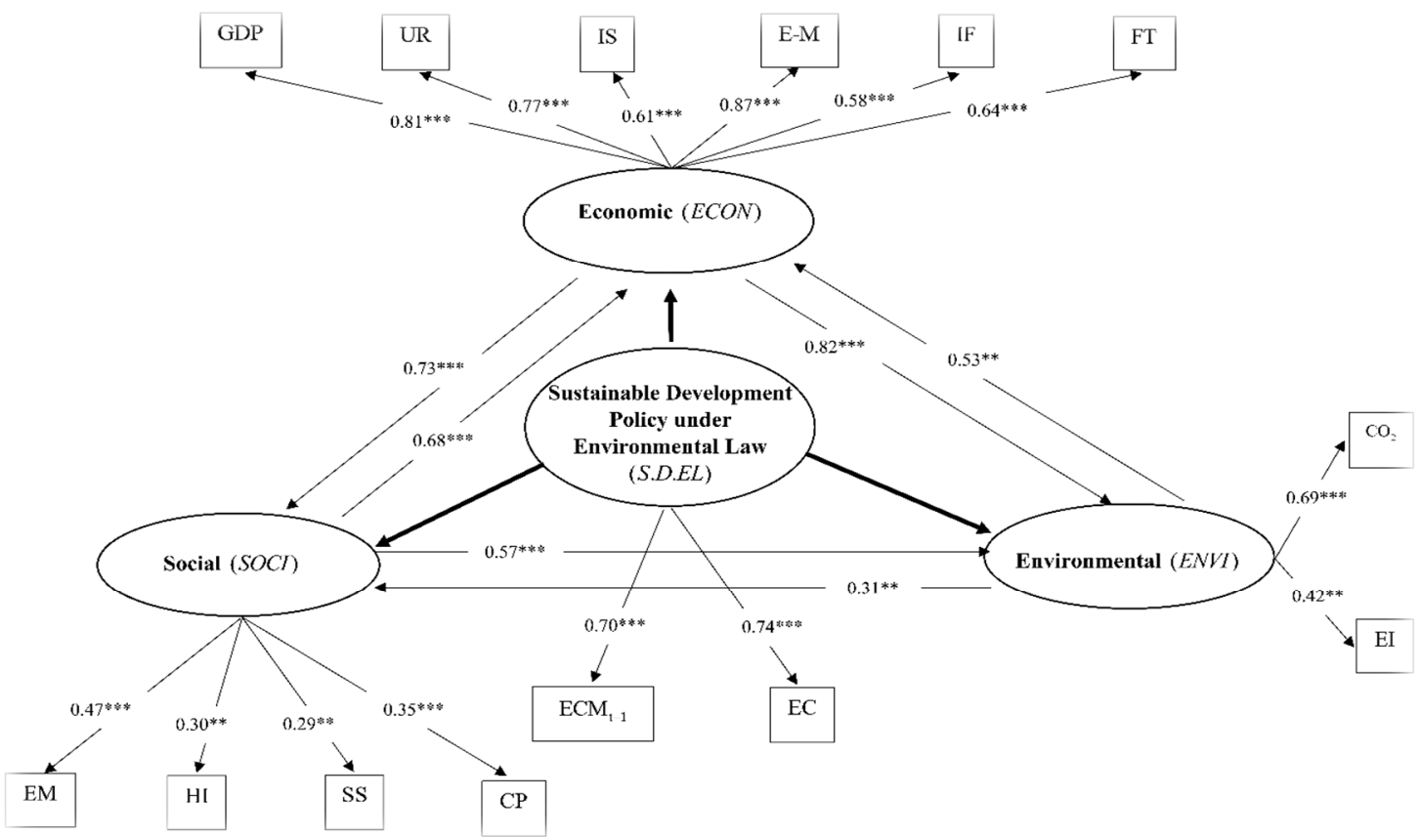

Figure 2. The casual relationship in the SEM-VARIMAX model.

Table 3. Results of the relationship of size analysis of the structural equation modeling/vector autoregressive model with exogenous variables (SEM-VARIMAX) model.

\begin{tabular}{cccccc}
\hline \multirow{2}{*}{$\begin{array}{c}\text { Dependent } \\
\text { Variables }\end{array}$} & $\begin{array}{c}\text { Type } \\
\text { of }\end{array}$ & \multicolumn{3}{c}{ Independent Variables } \\
\cline { 3 - 5 } & Effect & Economic $(E C O N)$ & Social $(S O C I)$ & Environmental $(E N V I)$ & Error Correction Mechanism $\left(\boldsymbol{E C M}_{\boldsymbol{t}-1}\right)$ \\
\hline Economic & DE & - & $0.68^{* * *}$ & $0.53^{* *}$ & $-0.39^{* * *}$ \\
$(E C O N)$ & IE & - & $0.05^{* * *}$ & $0.02^{* *}$ & - \\
\hline Social & DE & $0.73^{* * *}$ & - & $0.31^{* *}$ & $-0.26^{* * *}$ \\
$(S O C I)$ & IE & - & - & $0.09^{* *}$ & - \\
\hline Environmental & DE & $0.82^{* * *}$ & $0.57^{* * *}$ & - & $-0.05^{* * *}$ \\
$(E N V I)$ & IE & $0.12^{* *}$ & $0.09^{* * *}$ & - & - \\
\hline
\end{tabular}

Note: In the above, ${ }^{* * *}$ denotes significance $\alpha=0.01,{ }^{* *}$ denotes significance $\alpha=0.05, \chi^{2} / \mathrm{df}$ is 1.19 , RMSEA is 0.05 , RMR is 0.003 , GFI is 0.95 , AGFI is 0.90 , R-squared is 0.94 , the F-statistic is 225.05 (probability is 0.00 ), the ARCH test is 22.85 (probability is 0.1 ), the LM test is 1.35 (probability is 0.10 ), $\mathrm{DE}$ is the direct effect, and IE is the indirect effect.

\subsection{Formation of Analysis Modeling with the SEM-VARIMAX Model}

The SEM-VARIMAX model is a model that consists of short-term and long-term causal relationships, which show the impact of the latent variables, with the analysis explained as follows.

Figure 2 shows the impact of the causal factor relationship in the SEM-VARIMAX model determined by Sustainable development policy under environmental law (S.D.EL), where the latent variables are: economic $(E C O N)$, social $(S O C I)$, and environmental $(E N V I)$; the observed variables consist of energy consumption $(E C)$, per capita GDP $(G D P)$, urbanization rate (UR), industrial structure (IS), net exports $(E-M)$, indirect foreign investment $(I F)$, foreign tourists $(F T)$, employment $(E M)$, health 
and illness $(\mathrm{HI})$, social security $(\mathrm{SS})$, consumer protection $(\mathrm{CP})$, Carbon dioxide emissions $\left(\mathrm{CO}_{2}\right)$, energy intensity $(E I)$, and error correction mechanism $\left(E C M_{t-1}\right)$. The study findings reveal which factors had direct and indirect effects, as can be seen in Table 3.

Table 3 illustrates the parameters of the SEM-VARIMAX model at the statistically significant level of $1 \%$ and $5 \%$. With the analyzed findings, the SEM-VARIMAX model features with the goodness of fit standards, where the value of RMSEA and RMR is not far from 0 (zero), while the GFI and AGFI values approach 1. Furthermore, the BLUE testing indicates that the SEM-VARIMAX model has a BLUE feature, indicating that the model is not spurious yet it is reliable. This is due to the absence of heteroskedasticity, multicollinearity, and autocorrelation. In contrast, the F-test matters at the significance level of 1\%. Besides, the SEM-VARIMAX model explains a lot about the model featured under Sustainable Development Policy with Environmental Law (S.D.EL). In detail, the economic factor $(E C O N)$ has a direct impact on the environmental factor $(E N V I)$ amounting to $82 \%$ at a significance level of $1 \%$, the economic factor (ECON) has a direct impact on the social factor $(S O C I)$ of $73 \%$ at a significance level of $1 \%$, the social factor $(S O C I)$ has a direct impact on the environmental factor $(E N V I)$ totaling $57 \%$ at a significance level of $1 \%$, the environmental factor $(E N V I)$ has a direct impact on the social factor (SOCI) at 31\% at a significance level of $5 \%$, and the environmental factor $(E N V I)$ has a direct effect on the economic factor $(E C O N)$ of $53 \%$ at a significance level of $5 \%$.

In the case of $E C M_{t-1}$, this has a direct effect on the economic factor $(E C O N)$, where the parameter value is -0.39 at a significance level of $1 \%$, suggesting that the economic factor $(E C O N)$ has the ability to adjust toward the equilibrium at $39 \%$. For the same case of $E C M_{t-1}$, this has a direct effect on social factor $(S O C I)$, where the parameter value is -0.26 at a significance level of $1 \%$, telling us that the social factor (SOCI) has the same stated ability of $26 \%$, as is the same for $E C M_{t-1}$, which has a direct effect on the environmental factor $(E N V I)$, where the parameter value is -0.05 at a significance level of $1 \%$, showing that the environmental factor (ENVI) has the same ability at $5 \%$.

As for this SEM-VARIMAX mode, it has been measured for performance monitoring of the forecasting model in comparison with other models, including the MLR, BP, Grey, ANN, ANFIS, and ARIMA models by using the MAPE and RMSE, as illustrated below.

Table 4 explains the SEM-VARIMAX model in terms of MAPE and RMSE, and they are found to be lower than any other existing model at $1.06 \%$ and $1.19 \%$, respectively. If considering the performance monitoring result of the forecasting model for other models, the following was found. For the ARIMA model, its MAPE and RMSE were $6.29 \%$ and $3.41 \%$, respectively; the ANFIS model generated MAPE and RMSE with a value of $6.42 \%$ and $6.89 \%$, respectively; the ANN model generated MAPE and RMSE with a value of $8.65 \%$ and $10.15 \%$, respectively; the Grey model generated MAPE and RMSE with a value of $12.11 \%$ and $14.48 \%$, respectively; the BP model generated MAPE and RMSE with a value of $13.50 \%$ and $16.87 \%$, respectively; and the MLR model generated MAPE and RMSE with a value of $20.06 \%$ and $22.91 \%$, respectively.

Table 4. Performance monitoring of the forecasting models.

\begin{tabular}{ccc}
\hline Forecasting Model & MAPE (\%) & RMSE (\%) \\
\hline MLR model & 20.06 & 22.91 \\
BP model & 13.50 & 16.87 \\
Grey model & 12.11 & 14.48 \\
ANN model & 8.65 & 10.15 \\
ANFIS model & 6.42 & 6.89 \\
ARIMA model & 6.29 & 3.41 \\
SEM-VARIMAX model & 1.06 & 1.19 \\
\hline
\end{tabular}

Therefore, the above calculations show that the SEM-VARIMAX model is particularly suitable for future forecasting, especially long-term forecasting to support in strategy and effective planning. 
4.4. The Forecasting Model and the Efficiency of the Sustainable Development Policy for Energy Consumption under Environmental Law in Thailand based on the SEM-VARIMAX model

For forecasting purposes, the SEM-VARIMAX model was applied to predict energy consumption for the next 17 years (2020-2036) so as to gauge the efficiency of the Sustainable Development Policy in Energy Consumption under Environmental Law in Thailand based on the national strategy set to support policy formulation of Thailand in the future (from the present to 2036), as illustrated in Figure 3.

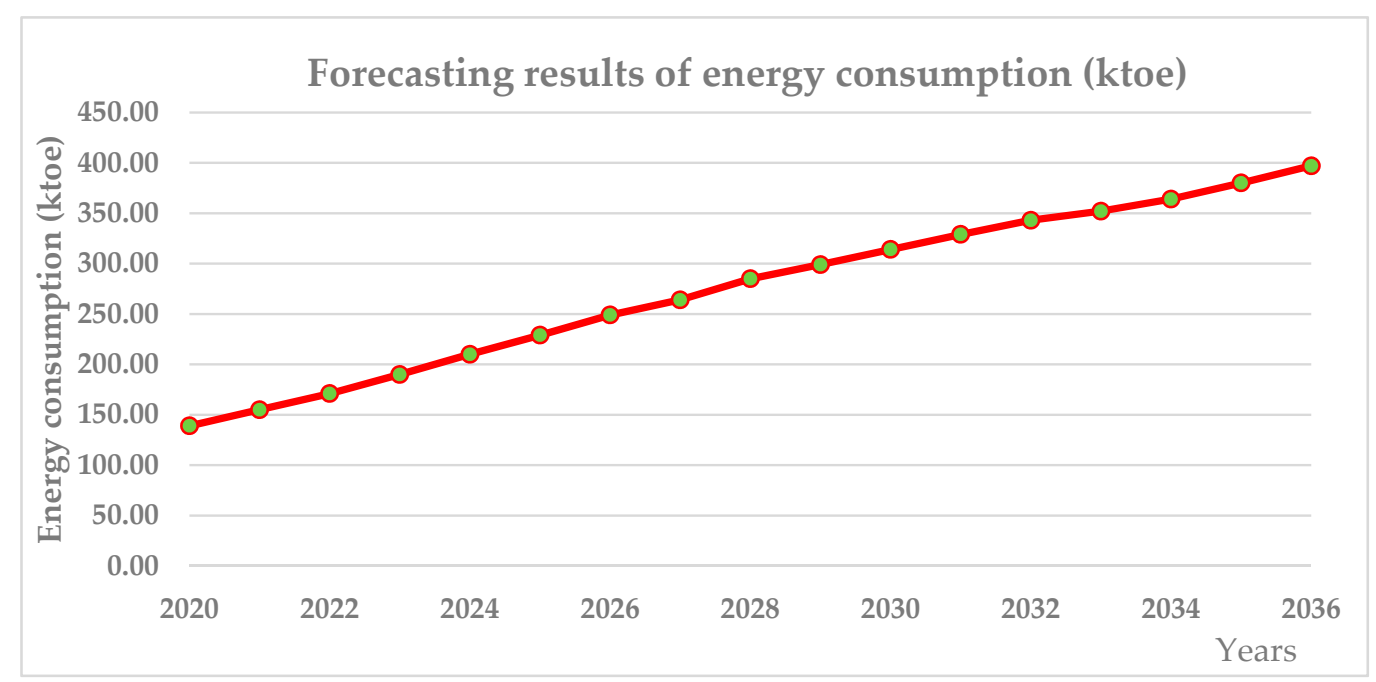

Figure 3. The forecasting results of energy consumption from 2020 to 2036 in Thailand.

Figure 3 shows that energy consumption from 2020 to 2036 under the Sustainable Development Policy for Energy Consumption under Environmental Law in Thailand will continuously increase from 2020 to 2036 with an increased growth rate from 185.66 (2036/2020) to 397.08 ktoe by 2536.

\section{Conclusions and Discussion}

This research was developed from relevant theories and advanced statistics to develop the SEM-VARIMAX model. This model differs from previous ones because it attempts to close several gaps and generate a functional model for the present, leading to research outcomes that are inclusive of special features relevant to different sectors and contexts. The software used in this research was LISREL incorporating EVIEWS, which are widely regarded to be the best choices for application. This research was conducted thoroughly and carefully while considering factors that influence policy implementation. This effort differentiates this research from other studies. In addition, this forecasting model determines real relationships between relevant causal and influential factors and the efficiency of Sustainable Development Policy for Energy Consumption under Environmental Law in Thailand (S.D.EL). The model comprises three latent variables: economic (ECON), social $(S O C I)$, and environmental (ENVI) factors, while the observed variables are energy consumption $(E C)$, per capita GDP $(G D P)$, urbanization rate $(U R)$, industrial structure $(I S)$, net exports $(E-M)$, indirect foreign investment $(I F)$, foreign tourists $(F T)$, employment $(E M)$, health and illness $(H I)$, social security $(S S)$, consumer protection $(C P)$, Carbon dioxide emissions $\left(\mathrm{CO}_{2}\right)$ and energy intensity $(E I)$. Each factor has undergone various processes to ensure its significance. To the greatest extent possible, this research also eliminated potential issues that may lead to spurious results, a problem that is faced in the development of any model. This elimination ensures the absence of heteroskedasticity, multicollinearity, and autocorrelation $[103,110]$. In this research, we identified the relevant factors and their impact direction. Most importantly, the approach used was able to adjust each latent variable toward equilibrium, which renders it significant for studying the change and balance resulting from 
the Sustainable Development Policy for Energy Consumption under Environmental Law in Thailand. The key measurement indicator is the error correction mechanism. In addition, the SEM-VARIMAX model passed the qualification for the BLUE feature and thus met the goodness-of-fit requirements. This research also examined the performance of the model in terms of MAPE and RMSE values and compared them with those of existing models, including the MLR, BP, Gray, ANN, ANFIS, and ARIMA models. It was found that the SEM-VARIMAX model had the lowest MAPE and RMSE, followed by the ARIMA, ANFIS, ANN Grey, BP, and MLR models, ordered in descending performance.

The SEM-VARIMAX model was used to predict energy consumption for the period of 2020-2036, and energy consumption was found to have an increased growth rate from 185.66 (2036/2020) to 397.08 ktoe by 2036. This rate is obviously higher than the government's set target, which is 251.05 ktoe by 2036 . This further reflects the inefficiency of the Sustainable Development Policy for Energy Consumption under Environmental Law in Thailand; the findings predict the disruption of the government's plan for carrying capacity under the environmental law currently enforced in Thailand. In addition, this research found that the adjustment to the environmental equilibrium in Thailand can be measured by the parameter of the error correction mechanism. The value of the parameter reflected a low adjustment rate of only $5 \%$ in the environmental aspect, while the economic side had an adjustment rate of $39 \%$. For the social aspect, the adjustment rate was $26 \%$ of total capacity. This finding presents clear evidence of the inefficiency of the environmental law in Thailand. In fact, this law has not been fully updated and modernized for the current context.

Recommendations for the future application of this research include the selection of appropriate statistics and research procedures that fit efficient long-term forecasting. This forecasting requires the best model and a white-noise-type model. The findings of this research explicitly reveal that the country will be at disadvantage if the policy is implemented according to the past or present practice or according to ordinary least squares or only the ARIMA model is used in the research. Quality research must focus on the forecasting task, with an emphasis on forecasting quality and validity. This is to avoid any possible damage that may arise.

The limitation of this research is that Thailand's policy planning does not consider causal factors or their impact. This is evident from Thailand's attempt to improve the economy and society through the implementation of various measures. However, the environmental law in Thailand does not fit the current situation or context, which constantly change, leading to a failure to support a green environment. In addition, some factors were found to be inconsistent with the model because of the intervening factor of fuel price control and government interference in certain sectors, resulting in the imbalance between demand and supply. This further causes instability in these factors at certain times. However, long-term forecasting is always a challenging task that requires detail and consistency. The SEM-VARIMAX model can be applied to different contexts and sectors, but it has to be carefully utilized because of its in-depth analysis, complexity, and advanced statistics used in the modeling process. If this model is properly applied, it will have great potential to provide extensive knowledge in the future.

The policy recommendations of Thailand derived from this research all concern the environmental law of Thailand. Although Thailand currently has the National Environmental Quality Promotion and Preservation Act (Version 2) B.E. 2561, it is still too weak to achieve the efficiency of sustainable development policy under environmental law. This is due to the failure to achieve the determined target along with some weaknesses, that require correction. In order to improve the environmental law, the following is suggested.

1. Increase community participation in the management and preservation of natural resources and the environment. For instance, there is the requirement of community representatives, state and public representatives who are elected or nominated to be part of the National Environment Board (Category 1).

2. Revisit the direction of the National Environmental Development Plan locally, provincially and nationally. 
3. Adopt the concept and philosophy of Thai traditions about the environment, as well as universal environmental law concepts, such as environmental justice being integrated into the constitution, so that the law and ordinances become supportive.

4. There are currently many environmental laws under different wings of administrations. Therefore, this has to be organized and systemized.

5. At present, the environmental case is under the judicial process of both the civil court and administrative court. Hence, all environmental cases shall be dealt with only by the administrative court, as the cases are wholly a matter of environmental justice, relating to the benefits of individuals, society and public interest. This settlement requires special expertise, which differs from civil cases. This further requires a revision of the law to switch the jurisdiction.

6. Mobilize scientific experts about the environment in various fields to help making legal decisions, conducting research, and developing environmental knowledge, as well as keeping environmental laws up to date.

7. Revise the processes and penalties from the polluter pays principle (PPP) with serious implementation and clarity.

Author Contributions: P.S. and S.N. were involved in the data collection and preprocessing phase, model constructing, empirical research, results analysis and discussion, and manuscript preparation. Both authors have approved the submitted manuscript.

Funding: This research received no external funding.

Acknowledgments: This research is supported by the School of Law, Assumption University.

Conflicts of Interest: The authors declare no conflict of interest.

\section{References}

1. Savaresi, A. The Paris Agreement: An Early Assessment. Environ. Policy Law 2016, 46, 14-18.

2. Laina, E. Sustainable Development in Operation. Environ. Policy Law 2016, 46, 47-49.

3. Sustainable Development Goals. Available online: http://www.solarimpulse.com/sustainable-developmentgoals? (accessed on 30 June 2019).

4. Krapp, R. Sustainable Development in the Second Committee. Environ. Policy Law 2016, 46, 10-13.

5. Uddin, M.K. Climate Change and Global Environmental Politics: North-South Divide. Environ. Policy Law 2017, 46, 106-114. [CrossRef]

6. Moore, P.; Pereira, E.S.; Duggin, G. Developing Environmental Law for All Citizens. Environ. Policy Law 2015, 45, 88-98.

7. Global Goals and the Environment: Progress and prospects. Available online: https://www.iisd.org/library/ global-goals-and-environment-progress-and-prospects (accessed on 30 June 2019).

8. Savaresi, A. Developments in Environmental Law. Environ. Policy Law 2012, 42, 365-369.

9. Office of Natural Resources and Environmental Policy and Planning. Available online: http://www.onep.go.th (accessed on 1 April 2019).

10. Office of the National Economic and Social Development Board (NESDB). Available online: http://www. nesdb.go.th/nesdb_en/more_news.php?cid=154\&filename=index (accessed on 1 April 2019).

11. National Statistic Office Ministry of Information and Communication Technology. Available online: http://web.nso.go.th/index.htm (accessed on 1 April 2019).

12. Department of Alternative Energy Development and Efficiency. Available online: http://www.dede.go.th/ ewtadmin/ewt/dede_web/ewt_news.php?nid=47140 (accessed on 2 April 2019).

13. Thailand Greenhouse Gas Management Organization (Public Organization). Available online: http: //www.tgo.or.th/2015/thai/content.php?s1=7\&s2=16\&sub3=sub3 (accessed on 2 April 2019).

14. Achawangkul, Y. Thailand's Alternative Energy Development Plan. Available online: http://www.unescap. org/sites/default/files/MoE\%20_\%20AE\%20policies.pdf (accessed on 3 April 2019).

15. Zhou, K.; Zhang, H.; Baum, J.; Chen, W. The Evolution of Policy and Law for Sustainable Development in China. Front. Law China 2014, 9, 389-402. 
16. Fan, K.-K.; Feng, T.-T. Discussion on Sustainable Development Strategies of the Traditional Handicraft Industry Based on Su-Style Furniture in the Ming Dynasty. Sustainability 2019, 11, 8. [CrossRef]

17. Boyd, E.; Hultman, N.; Roberts, J.T.; Corbera, E.; Cole, J.; Bozmoski, A.; Ebeling, J.; Tippman, R.; Mann, P.; Brown, K.; et al. Reforming the CDM for sustainable development: Lessons learned and policy futures. Environ. Sci. Policy 2009, 12, 280-831. [CrossRef]

18. Joseph, C. Understanding sustainable development concept in Malaysia. Soc. Responsib. J. 2013, 9, 441-453. [CrossRef]

19. Bahauddin, K.M. Environmental system management and governance needs in a developing country. Environ. Syst. Decis. 2014, 34, 342-357. [CrossRef]

20. Rivera, M. Political Criteria for Sustainable Development Goal (SDG) Selection and the Role of the Urban Dimension. Sustainability 2013, 5, 5034-5051. [CrossRef]

21. Ali, S.; Bibi, M.; Rabbi, F. A New Economic Dimension to the Environmental Kuznets Curve: Estimation of Environmental Efficiency in Case of Pakistan. Asian Econ. Financ. Rev. 2014, 4, 68-79.

22. Pinkse, J.; Kolk, A. Addressing the Climate Change-Sustainable Development Nexus: The Role of Multistakeholder Partnerships. Bus. Soc. 2012, 51, 176-210. [CrossRef]

23. Choi, S.; Ng, A. Environmental and Economic Dimensions of Sustainability and Price Effects on Consumer Responses. J. Bus. Ethics 2011, 104, 269-282. [CrossRef]

24. Amesheva, I. Environmental Degradation and Economic Development in China: An Interrelated Governance Challenge. Law Dev. Rev. 2017, 10, 425-450. [CrossRef]

25. Bakari, M.E.K. Sustainable Development in a Global Context: A Success or a Nuisance? New Glob. Stud. 2015, 9, 27-56. [CrossRef]

26. Martin, E.J. Economic rights, sustainable development, and environmental management. Public Adm. Manag. 2011, 16, 121-144.

27. United Nations Secretariat. Urbanization and sustainable development in Asia and the Pacific: Linkages and policy implications. Available online: https:/www.unescap.org/commission/73/document/E73_16E.pdf (accessed on 1 April 2019).

28. Khalifa, M.A.; Connelly, S. Monitoring and guiding development in rural Egypt: Local sustainable development indicators and local Human Development Indices. Environ. Dev. Sustain. 2009, 11, 1175-1196. [CrossRef]

29. Wuelser, G.; Pohl, C.; Hadorn, G.H. Structuring complexity for tailoring research contributions to sustainable development: A framework. Sustain. Sci. 2012, 7, 81-93. [CrossRef]

30. Mueller, M.; Dos Santos, V.G.; Seuring, S. The Contribution of Environmental and Social Standards towards Ensuring Legitimacy in Supply Chain Governance. J. Bus. Ethics 2009, 89, 509-523. [CrossRef]

31. Zhang, L.; Dzakpasu, M.; Chen, R.; Wang, X.C. Validity and utility of ecological footprint accounting: A state-of-the-art review. Sustain. Cities Soc. 2017, 32, 411-416. [CrossRef]

32. Wang, Y.; Jiang, Y.; Zheng, Y.; Wang, H. Assessing the Ecological Carrying Capacity Based on Revised Three-Dimensional Ecological Footprint Model in Inner Mongolia, China. Sustainability 2019, 11, 2002. [CrossRef]

33. Singh, R.; Debnath, R.M. Modeling sustainable development: India's strategy for the future. World J. Sci. Technol. Sustain. Dev. 2012, 9, 120-135. [CrossRef]

34. Giddings, B.; Hopwood, B.; O’Brien, G. Environment, economy and society: Fitting them together into sustainable development. Sustain. Dev. 2002, 10, 187-196. [CrossRef]

35. Sapukotanage, S.; Warnakulasuriya, B.N.F.; Yapa, S.T.W.S. Outcomes of Sustainable Practices: A Triple Bottom Line Approach to Evaluating Sustainable Performance of Manufacturing Firms in a Developing Nation in South Asia. Int. Bus. Res. 2018, 11, 89-104. [CrossRef]

36. Sutthichaimethee, P. Forecasting Economic, Social and Environmental Growth in the Sanitary and Service Sector Based on Thailand's Sustainable Development Policy. J. Ecol. Eng. 2018, 19, 205-210. [CrossRef]

37. Greaker, M.; Stoknes, P.E.; Alfsen, K.H.; Ericson, T. A Kantian approach to sustainable development indicators for climate change. Ecol. Econ. 2013, 91, 10-18. [CrossRef]

38. Cetindamar, D.; Husoy, K. Corporate Social Responsibility Practices and Environmentally Responsible Behavior: The Case of the United Nations Global Compact. J. Bus. Ethics 2007, 76, 163-176. [CrossRef]

39. Bedore, J. An Evaluation of Canada's Environmental Sustainability Planning System and the Federal Sustainable Development. Act. Master's Thesis, Queen's University, Kingston, ON, Canada, 2008. 
40. Lee, D.; Park, H.; Park, S.K. Policy Issues for Contributing ODA to Sustainable Development in Developing Countries: An Analysis of Korea's ODA and Sri Lankan Practices. Asian Perspect. 2018, 42, 623-646. [CrossRef]

41. Aguilera-Caracuel, J.; Aragon-Correa, J.A.; Hurtado-Torres, N.E.; Rugman, A.M. The Effects of Institutional Distance and Headquarters' Financial Performance on the Generation of Environmental Standards in Multinational Companies. J. Bus. Ethics 2012, 105, 461-474. [CrossRef]

42. Pires, S.M.; Fidélis, T.; Ramos, T.B. Measuring and comparing local sustainable development through common indicators: Constraints and achievements in practice. Cities 2014, 39, 1-9. [CrossRef]

43. Giannetti, B.F.; Demétrio, J.F.C.; Bonilla, S.H.; Agostinho, F.; Almeidan, C.M.V.B. Emergy diagnosis and reflections towards Brazilian sustainable development. Energy Policy 2013, 63, 1002-1012. [CrossRef]

44. Wysokińska, Z. Millenium Development Goals/UN and Sustainable Development Goals/UN as Instruments for Realising Sustainable Development Concept in the Global Economy. Comp. Econ. Res. 2017, 20, 101-118. [CrossRef]

45. Pânzaru, S.; Dragomir, C. The Considerations of the Sustainable Development and Eco-Development in National and Zonal Context. Rev. Int. Comp. Manag. 2012, 13, 823-831.

46. Byrch, C.; Kearins, K.; Milne, M.; Morgan, R. Sustainable "what"? A cognitive approach to understanding sustainable development. Qual. Res. Account. Manag. 2007, 4, 26-52. [CrossRef]

47. Casey, G.; Galor, O. Population Growth and Carbon Emissions. Available online: https://www.brown.edu/ academics/economics/sites/brown.edu.academics.economics/files/uploads/2016-8_paper_0.pdf (accessed on 1 April 2019).

48. Ramakrishnan, S.; Hishan, S.S.; Nabi, A.A.; Arshad, Z.; Kanjanapathy, M.; Zaman, K.; Khan, F. An interactive environmental model for economic growth: Evidence from a panel of countries. Environ. Sci. Pollut. Res. 2016, 23, 14567-14579. [CrossRef]

49. Ladan, M.T. Achieving Sustainable Development Goals through Effective Domestic Laws and Policies on Environment and Climate Change. Environ. Policy Law 2018, 48, 42-63. [CrossRef]

50. Craig, K.R.; Garmestani, A.S.; Allen, C.R.; Arnold, C.A.; Birgé, H.; DeCaro, D.A.; Fremier, A.K.; Gosnell, H.; Schlager, E. Balancing stability and flexibility in adaptive governance: An analysis of tools available in U.S. environmental law. Ecol. Soc. 2017, 22, 3. [CrossRef]

51. Wang, A.L. The Search for Sustainable Legitimacy: Environmental Law and Bureaucracy in China. Harv. Environ. Law Rev. 2013, 37, 365-440. [CrossRef]

52. Bartel, R.; Barclay, E. Motivational postures and compliance with environmental law in Australian agriculture. J. Rural Stud. 2011, 27, 153-170. [CrossRef]

53. Kim, R.E.; Mackey, B. International environmental law as a complex adaptive system. Int. Environ. Agreem. 2014, 14, 5-23. [CrossRef]

54. Huber, B.R. Transition Policy in Environmental Law. Harv. Environ. Law Rev. 2011, 35, 91-130.

55. Tecklin, D.; Bauer, C.; Prieto, M. Making environmental law for the market: The emergence, character, and implications of Chile's environmental regime. Environ. Politics 2011, 20, 879-898. [CrossRef]

56. Zeben, J.V. Subsidiarity in European Environmental Law: A Competence Allocation Approach. Harv. Environ. Law Rev. 2014, 38, 415-464.

57. Bodansky, D. The Legitimacy of International Governance: A Coming Challenge for International Environmental Law? Am. J. Int. Law 1999, 93, 596-624. [CrossRef]

58. Heinzerling, L. New directions in environmental law: A climate of possibility. Harv. Environ. Law Rev. 2011, 35, 263-273.

59. Chang, Y.-C.; Wang, N. Environmental regulations and emissions trading in China. Energy Policy 2010, 38, 3356-3364. [CrossRef]

60. Periconi, J.J.; Jokajtys, M.R. Shining Some Light Back on the Dark Ages: New York State's Early Environmental Law and Its Implications for Today's Environmental Insurance Coverage Disputes. Environ. Claims J. 2014, 26, 287-300. [CrossRef]

61. Latham, M.; Schwartz, V.E.; Appel, C.E. The intersection of tort and environmental law: Where the twains should meet and depart. Law Rev. 2011, 80, 737-773.

62. Wood, M.C. "You Can't Negotiate with a Beetle": Environmental Law for a New Ecological Age. Nat. Resour. J. 2010, 50, 167-210.

63. Gibson, R.B. In full retreat: The Canadian government's new environmental assessment law undoes decades of progress. Impact Assess. Proj. Apprais. 2012, 30, 179-188. [CrossRef] 
64. Fast, H.; Fitzpatrick, P. Modernizing environmental protection in Manitoba: The environmental bill of rights as one component of environmental reform. J. Environ. Law Pract. 2017, 30, 295-320.

65. De Moerloose, S. Law and Development as a Field of Study: Connecting Law with Development. Law Dev. Rev. 2017, 10, 179-186. [CrossRef]

66. Tania, S.J. Is There a Linkage Between Sustainable Development and Market Access of LDCs? Law Dev. Rev. 2013, 6, 143-223. [CrossRef]

67. Chepaitis, D.J.; Panagakis, A. Individualism Submerged: Climate Change and the Perils of an Engineered Environment. UCLA J. Environ. Law Policy 2010, 28, 291-342.

68. Miao, H. Sustainable Development through the Right to Access to Justice in Environmental Matters in China. Sustainability 2019, 11, 900.

69. Pourhashemi, S.A.; Khoshmaneshzadeh, B.; Soltanieh, M.; Hermidasbavand, D. Analyzing the individual and social rights condition of climate refugees from the international environmental law perspective. Int. J. Environ. Sci. Technol. 2012, 9, 57-67. [CrossRef]

70. Ruhl, J.B. Climate Change Adaptation and the Structural Transformation of Environmental Law. Environ. Law 2009, 40, 363-431.

71. Moreno, E.M.O.; de Luna, E.B.; Gómez, M.D.C.O.; López, E.J. Structural Equations Model (SEM) of a questionnaire on the evaluation of intercultural secondary education classrooms. Suma Psicol. 2014, 21, 107-115. [CrossRef]

72. Boccia, F.; Sarnacchiaro, P. Structural Equation Model for the Evaluation of Social Initiatives on Customer Behaviour. Procedia Econ. Financ. 2014, 17, 211-220. [CrossRef]

73. Baumgartnar, H.; Homburg, C. Applications of Structural equation modeling in marketing and consumer research: A review. Int. J. Res. Mark. 1996, 13, 139-161. [CrossRef]

74. Mai, Y.; Zhang, Z.; Wen, Z. Comparing Exploratory Structural Equation Modeling and Existing Approaches for Multiple Regression with Latent Variables. Struct. Equ. Model. Multidiscip. J. 2018, 25, 737-749. [CrossRef]

75. Ryu, E.; Mehta, P. Multilevel Factorial Invariance in n-Level Structural Equation Modeling (NSEM). Struct. Equ. Model. Multidiscip. J. 2017, 24, 936-959. [CrossRef]

76. Lei, M.; Lomax, R.G. The Effect of Varying Degrees of Nonnormality in Structural Equation Modeling. Struct. Equ. Model. Multidiscip. J. 2005, 12, 1-27. [CrossRef]

77. Cugnata, F.; Kenett, R.; Salini, S. Bayesian Network Applications to Customer Surveys and InfoQ. Procedia Econ. Financ. 2014, 17, 3-9. [CrossRef]

78. Nylund, K.L.; Asparouhov, T.; Muthen, B.O. Deciding on the Number of classes in Latent Class Analysis and Growth Mixture Modeling: A Monte Carlo Simulation Study. Struct. Equ. Model. Multidiscip. J. 2007, 14, 534-569. [CrossRef]

79. Saito, M.; Kato, T.; Tang, Y. Temperature controls ecosystem $\mathrm{CO}_{2}$ exchange of an alpine meadow on the northeastern Tibetan Plateau. Glob. Chang. Biol. 2009, 15, 221-228. [CrossRef]

80. Yang, M.; Yuan, K.H. Optimizing Ridge Generalized Least Squares for Structural Equation Modeling. Struct. Equ. Model. Multidiscip. J. 2019, 26, 24-38. [CrossRef]

81. Chang, C.J.; Li, G.; Zhang, S.Q.; Yu, K.P. Employing a Fuzzy-Based Grey Modeling Procedure to Forecast China's Sulfur Dioxide Emissions. Int. J. Environ. Res. Public Health 2019, 16, 2504. [CrossRef]

82. Wang, H.; Huang, J.; Zhou, H.; Zhao, L.; Yuan, Y. An Integrated Variational Mode Decomposition and ARIMA Model to Forecast Air Temperature. Sustainability 2019, 11, 4018. [CrossRef]

83. Ma, L.; Wu, M.; Tian, X.; Zheng, G.; Du, Q.; Wu, T. China's Provincial Vehicle Ownership Forecast and Analysis of the Causes Influencing the Trend. Sustainability 2019, 11, 3928. [CrossRef]

84. Zhao, L.T.; Liu, L.N.; Wang, Z.J.; He, L.Y. Forecasting Oil Price Volatility in the Era of Big Data: A Text Mining for VaR Approach. Sustainability 2019, 11, 3892. [CrossRef]

85. Xiong, P.; Shi, J.; Pei, L.; Ding, S. A Novel Linear Time-Varying GM(1,N) Model for Forecasting Haze: A Case Study of Beijing, China. Sustainability 2019, 11, 3832. [CrossRef]

86. Zhao, L.; Liu, Z.; Mbachu, J. Energy Management through Cost Forecasting for Residential Buildings in New Zealand. Energies 2019, 12, 2888. [CrossRef]

87. Barari, M.; Kundu, S. The Role of the Federal Reserve in the U.S. Housing Crisis: A VAR Analysis with Endogenous Structural Breaks. J. Risk Financ. Manag. 2019, 12, 125. [CrossRef]

88. Tucki, K.; Orynycz, O.; Świć, A.; Wojtanek, M.M. The Development of Electromobility in Poland and EU States as a Tool for Management of $\mathrm{CO}_{2}$ Emissions. Energies 2019, 12, 2942. [CrossRef] 
89. Ahmed, M.; Sultan, M.; Elbayoumi, T.; Tissot, P. Forecasting GRACE Data over the African Watersheds Using Artificial Neural Networks. Remote Sens. 2019, 11, 1769. [CrossRef]

90. Ramsauer, F.; Min, A.; Lingauer, M. Estimation of FAVAR Models for Incomplete Data with a Kalman Filter for Factors with Observable Components. Econometrics 2019, 7, 31. [CrossRef]

91. Sutthichaimethee, P.; Kubaha, K. The Efficiency of Long-Term Forecasting Model on Final Energy Consumption in Thailand's Petroleum Industries Sector: Enriching the LT-ARIMAXS Model under a Sustainability Policy. Energies 2018, 11, 2063. [CrossRef]

92. Sutthichaimethee, P.; Kubaha, K. A Relational Analysis Model of the Causal Factors Influencing $\mathrm{CO}_{2}$ in Thailand's Industrial Sector under a Sustainability Policy Adapting the VARIMAX-ECM Model. Energies 2018, 11, 1704. [CrossRef]

93. Jöreskog, K.G.; Sörbom, D. New Features in LISREL 8; Chicago Scientific Software International: Chicago, IL, USA, 1993.

94. Hunter, M.D. State Space Modeling in an Open Source, Modular. Struct. Equ. Model. Multidiscip. J. 2018, 25, 304-324. [CrossRef]

95. Sutthichaimethee, P.; Dockthaisong, B. A Relationship of Causal Factors in the Economic, Social, and Environmental Aspects Affecting the Implementation of Sustainability Policy in Thailand: Enriching the Path Analysis Based on a GMM Model. Resources 2018, 7, 87. [CrossRef]

96. Dickey, D.A.; Fuller, W.A. Likelihood ratio statistics for autoregressive time series with a unit root. Econometrica 1981, 49, 1057-1072. [CrossRef]

97. Johansen, S.; Juselius, K. Maximum likelihood estimation and inference on cointegration with applications to the demand for money. Oxf. Bull. Econ. Stat. 1990, 52, 169-210. [CrossRef]

98. Johansen, S. Likelihood-Based Inference in Cointegrated Vector Autoregressive Models; Oxford University Press: New York, NY, USA, 1995.

99. MacKinnon, J. Critical Values for Cointegration Test in Long-Run Economic Relationships; Engle, R., Granger, C., Eds.; Oxford University Press: Oxford, UK, 1991.

100. Wall, M.M.; Li, R. Comparison of multiple regression to two latent variable techniques for estimation and prediction. Stat. Med. 2003, 22, 3671-3685. [CrossRef]

101. Enders, W. Applied Econometrics Time Series; Wiley Series in Probability and Statistics; University of Alabama: Tuscaloosa, AL, USA, 2010.

102. Harvey, A.C. Forecasting, Structural Time Series Models and the Kalman Filter; Cambridge University Press: Cambridge, UK, 1989.

103. Lim, S.; Melville, N.P. Robustness of Structural Equation Modeling to Distributional Misspecification: Empirical Evidence \& Research Guidelines. Available online: http://ssrn.com/abstract=1375251 (accessed on 31 August 2019).

104. Sutthichaimethee, P.; Ariyasajjakorn, D. Forecast of Carbon Dioxide Emissions from Energy Consumption in Industry Sectors in Thailand. Environ. Clim. Technol. 2018, 22, 107-117. [CrossRef]

105. Sutthichaimethee, P.; Ariyasajjakorn, D. The revised input-output table to determine total energy content and total greenhouse gas emission factors in Thailand. J. Ecol. Eng. 2017, 18, 166-170. [CrossRef]

106. Sutthichaimethee, P. Varimax Model to Forecast the Emission of Carbon Dioxide from Energy Consumption in Rubber and Petroleum Industries Sectors in Thailand. J. Ecol. Eng. 2017, 18, 112-117. [CrossRef]

107. Sutthichaimethee, P.; Ariyasajjakorn, D. Forecasting Model of GHG Emission in Manufacturing Sectors of Thailand. J. Ecol. Eng. 2017, 18, 18-24. [CrossRef]

108. Sutthichaimethee, P. Modeling Environmental Impact of Machinery Sectors to Promote Sustainable Development of Thailand. J. Ecol. Eng. 2016, 17, 18-25. [CrossRef]

109. Sutthichaimethee, P. Model of Environmental Problems Priority Arising from the Use of Environmental and Natural Resources in Machinery Sectors of Thailand. Environ. Clim. Technol. 2016, 17, 18-29. [CrossRef]

110. Grewal, R.; Cote, J.A.; Baumgartner, H. Multicollinearity and Measurement Error in Structural Equation Models: Implications for Theory Testing. Mark. Sci. 2004, 23, 519-529. [CrossRef]

(C) 2019 by the authors. Licensee MDPI, Basel, Switzerland. This article is an open access article distributed under the terms and conditions of the Creative Commons Attribution (CC BY) license (http://creativecommons.org/licenses/by/4.0/). 